Volume 2

Number 2 Popular Culture and Markets in

Turkey

2017

\title{
The Paramountcy of Context: Introduction to Special Issue on Popular Culture and Markets in Turkey
}

\author{
Güliz Ger \\ Bilkent University
}

Follow this and additional works at: https://digitalcommons.uri.edu/mgdr

Part of the Anthropology Commons, Critical and Cultural Studies Commons, Economics Commons, Marketing Commons, Political Science Commons, and the Sociology Commons

\section{Recommended Citation}

Ger, Güliz (2017) "The Paramountcy of Context: Introduction to Special Issue on Popular Culture and Markets in Turkey," Markets, Globalization \& Development Review. Vol. 2: No. 2, Article 1.

DOI: 10.23860/MGDR-2017-02-02-01

Available at: https://digitalcommons.uri.edu/mgdr/vol2/iss2/1

This Editorial is brought to you for free and open access by DigitalCommons@URI. It has been accepted for inclusion in Markets, Globalization \& Development Review by an authorized editor of DigitalCommons@URI. For more information, please contact digitalcommons-group@uri.edu. 
The Paramountcy of Context: Introduction to Special Issue on Popular Culture and Markets in Turkey

\section{Markets, Globalization \& Development Review}
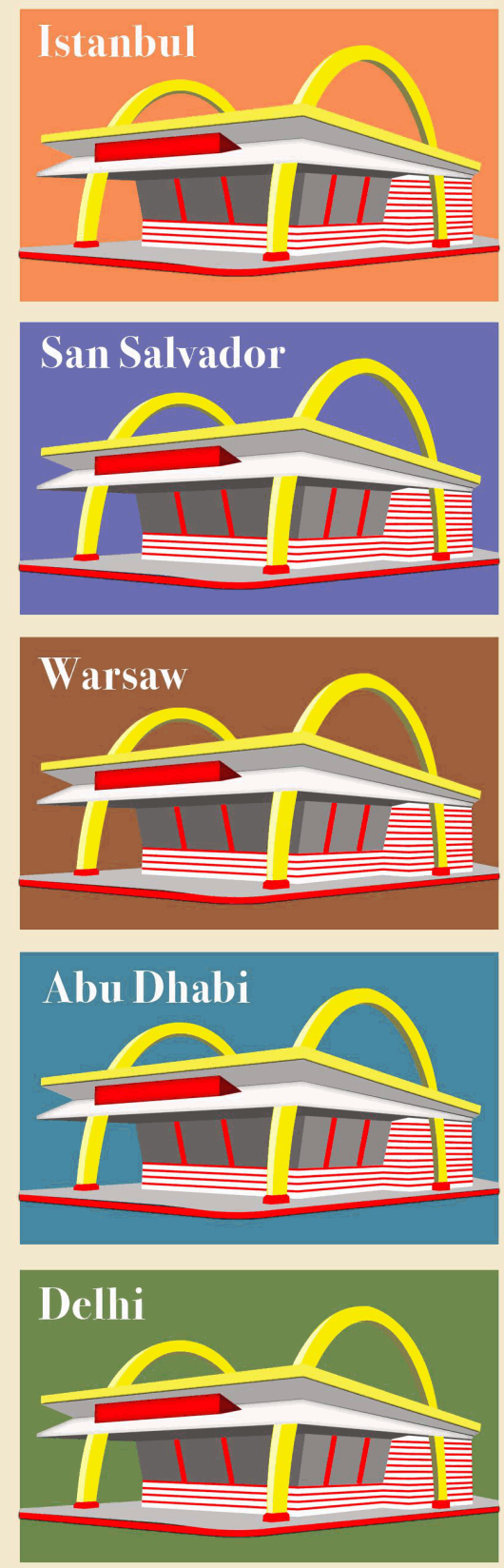
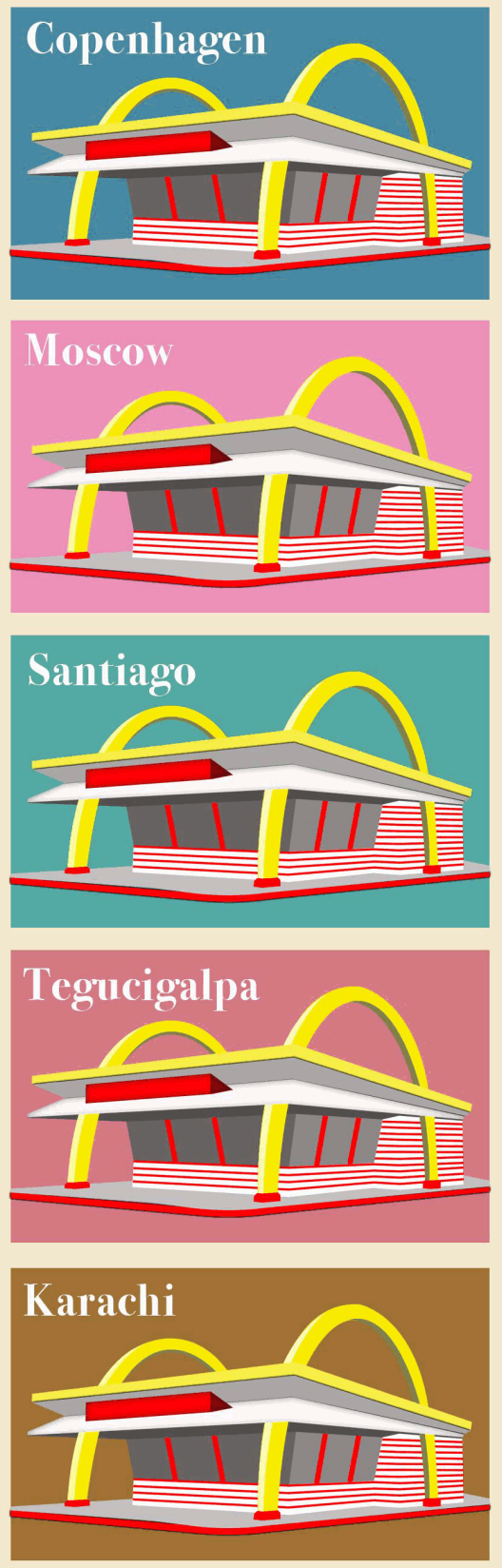
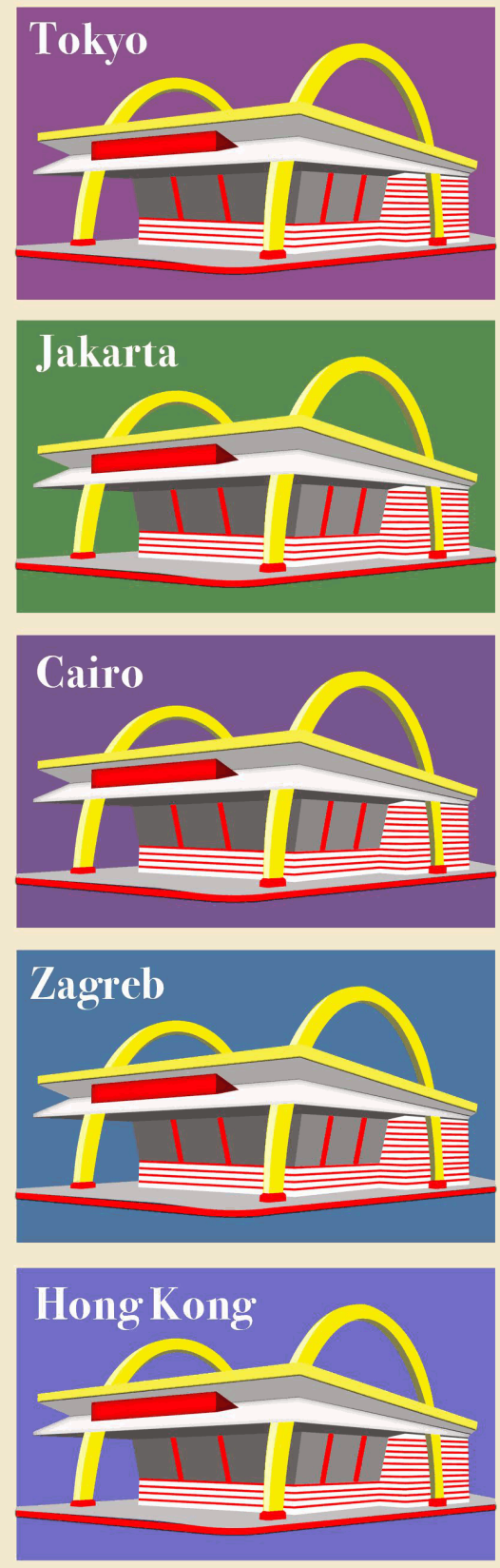

This editorial is available in Markets, Globalization \& Development Review: https://digitalcommons.uri.edu/mgdr/ vol2/iss $2 / 1$ 


\section{The Paramountcy of Context: Introduction to Special Issue on Popular Culture and Markets in Turkey}

This issue of MGDR exposes the embeddedness of markets and consumption (and research about markets) in their political and cultural contexts, in the specific case of Turkey. In an unsettling world of various fundamentalisms, un-progressive policies, globalization and anti-globalization, attention to the context of markets and development and the particular webs of contextual interrelations is paramount. With media being dominated by a handful of corporations strongly allied with governments, popular culture has become a strong force field, of soft international power and of populist domestic politics, particularly - but not solely - in developing or "emerging" geographies. From a Gramscian or Frankfurt school perspective, popular culture has never solely been an innocent matter of daily life aesthetics or entertainment. With the contemporary media structure, information technologies, and social media, however, popular culture has now become a more pervasive and influential political arena. Hence, this issue on popular culture and markets is largely an issue on the political context of markets and development.

Scholars interested in markets, globalization and development have acknowledged the structural context and the multifaceted nature of the phenomena they study. Extant phenomena in the real world have historical and contemporary cultural, social, political, material, and economic aspects. The embeddedness of these multiple dimensions necessitate that we study globalization, markets and development with multidisciplinary or interdisciplinary and intersectional lenses, approaches, and methods. The Annual Macromarketing Conference since 1976 and then the Journal of Macromarketing since 1981 have been spearheading the emphasis on the macro context of marketing and the interrelationships among marketing, society, and social change. Growing out of the Macromarketing Conference, the International Conference on Marketing and Development, later institutionalized in 1986 as the International Society of Markets and Development (ISMD), with its conferences in developing parts of the world and its proceedings, has been building an appreciation of a similar point: the interplay of development and markets in a globalizing and antiglobalizing world. A more recent (since 2006) conference and research tradition, Transformative Consumer Research (TCR), while usually embracing more micro perspectives, has had a similar thread of interest in well-being and social issues, thus, also going beyond the typical actors: the firm and the consumer. Most research coming out of business schools and economics departments, however, has remained insistently within the boundaries of firm performance and consumer satisfaction or identity. ISMD's journal Markets, Globalization \& 
Development Review (MGDR) now provides another venue for the voice of scholars who wish to go beyond such micro firm-consumer perspective.

Moreover, in examining globalization, it is time that we shift our perspective from the influential "flowspeak" to dominance and belonging relations within and across societies, and to situating the global flows in their specific local and global sociopolitical historical contexts (Bude and Dürrschmidt 2010; de Koning 2009; Ger 2017; Ger et al. 2017). The pervasiveness of global dominance relations and neoliberalism call for greater researcher reflexivity (see, for example, Özgün, Dholakia, and Atik 2017). While studying globalization, markets and development, such responsibility invites a focus on the historical as well as current structures that engender an experience, an event, a phenomenon, and/or a consequence. I hope that scholars confront the dominance structures that are critical in the contemporary world political stage. In such an endeavor, subaltern studies, postcolonial studies, and new social movements are some literatures - in addition to media studies and popular culture - which would help generate relevant and important research streams.

Of the five papers in this issue, three provide a lens on the importance of the political context for markets. One paper focuses on the role of the media in inciting consumption desires and one on innovative methodologies.

Özgün, Yurdakul and Atik (2017) explore the experiences of the poor Turkish women with television and the links to consumption. Finding soap operas to be the key programs watched, and noting the inaccessibility of other means of socialization and entertainment, they reason that soap operas are a key connection of poor women to the world beyond their neighborhood. Thus, they argue that soap operas, a major channel of exposure to consumer culture and marketing, incite consumption desires. While there are some cathartic emotional outcomes of this process, the exposure to soap operas deepens the contradiction between their current living conditions and what they perceive to be the life of others. There also are negative emotional and financial outcomes - credit card debt spiral, hopelessness, powerlessness, shame, and dissatisfaction. The authors note the crucial role of the government in providing and regulating public services to the benefit of the less privileged groups. Concerning the role of government, I wondered if and how these soap operas and their reception reflected the dominant neoconservative and neoliberal political ideology, which can be a relevant topic for a further research.

Watson (2017) shares his experience of conducting questionnaires in order to assess the opinions of villagers working on a farm in western Turkey. He finds that unlike the managers who work on the same farm, the villagers were reluctant to give independent 
answers. Instead they wanted to discuss the question and possible answers with their colleagues and then provide a common reply. Noting that opinions are intersubjectively generated, he proposes a "communal" questionnaire, which is a hybrid between a structured questionnaire, in-depth interview and focus group. Watson also provides a comparison of these methods. Watson's field experience and suggestion is an example of how we must rethink our ways of generating information and constructing knowledge, even with preformed questionnaires, if we want to engage constructively with the community we are researching. And in that regard, another pertinent method is participative action research.

Karanfil and Eğilmez (2017) discuss the recent emergence of two state-run television channels, which broadcast in the Middle East, North Africa, the Balkans, Central Asia and the Caucuses. They examine this emergence as a cultural flow in the global media, focusing on the media-culture-politics interplay. They contend that a national broadcaster transformed into a transnational one with a politico-cultural agenda, concurrent with changes in foreign policy and ideological discourse: neo-Ottomanism - revitalization of the religious and cultural character of the empire in the Turkish present. Karanfil and Eğilmez examine the content of three weeks' streaming for each channel during three different months and find three major themes: Islam, Anatolian culture and heritage, and Istanbul as the capital of the empire. They argue that as the Islamist government turned its face to Islamic and Arabic speaking societies in the region, these two public channels have become its transnational agents -deployed to exert a cultural (as well as economic) presence. I hope that in future studies, the interchange between such cultural and economic presence can be elaborated further.

Akın and Doğu (2017) explore the potentialities and the challenges of sustaining a civil society in the media and information technology (IT) fields in Turkey. They focus on the interplay between the spheres of media, IT, market configurations, and politics. They describe the attempts of nongovernmental associations and foundations to improve media production conditions, the freedom of the media, provide alternative (independent) media, fight for digital rights, free software activism, internet censorship, surveillance, and data protection. They delineate how media became a divided political field controlled by polarized corporations, aligned with the government. Akın and Doğu highlight challenges democratic media and IT NGOs encounter. They highlight the political and economic pressures on these civil society organizations, which try to survive within the power structure of the allied actors of the media moguls and the government, as well as their covert arm - the undemocratic media-related NGOs functioning in their interest. 
Subaşat (2017) reminds us of the fundamental connectedness of economics and politics, exemplified by the recent transformations in Turkey. He explicates the process aimed at political regime change deployed by the Islamist Justice and Development Party since they came to power. Subaşat recounts how economic policies, designed to create pseudo affluence and to stimulate short-term consumption, collaborated with politics and facilitated successive election victories.

In addition, this issue provides a book review and a film review. Gökmen (2017)'s review of Jan-Werner Müller's 2016 book titled "What is Populism?" notes the lack of a theory of populism and questions if recognizing the symptoms of a political disposition would help in the absence of a theory.

Treske (2017)'s review of Reha Erdem's 2016 film "The Big World" compels us to imagine life in nature juxtaposed to life in "civilized" world - with its orphanages and evil characters.

We glean insight into the intricacies of various webs of relations from each of the papers and reviews. What future research do these papers and reviews inspire? Historicizing particular marketdevelopment relations is one path. Going beyond a single empirical context, comparing similar and different findings/phenomena in other parts of the world, and thus extrapolating a more generalized understanding is another. Meta-analysis is yet another path. Contextualizing the context (Askegaard and Linnet 2011), especially the socio-political context, is a useful complementary route to each of the above. How a country, any country, and its market integrates into (or not) the global markets, the development pattern it pursues, can only be understood if the broader historical political context is understood, within the country as well as international political economy.

Last, but not the least, we would like to thank Deborah Hardt, lecturer at Izmir University of Economics, Cinema and Digital Media Department, for her meticulous and diligent work on copy-editing of the demanding manuscripts of this special issue. We also would like to thank Murad Canbulut, our managing editor, for his attentive work on the manuscripts. 


\section{References}

Akın, Altuğ and Burak Doğu (2017), "NGOs in Turkey's media field: Causes, sources and potentials for development," Markets, Globalization \& Development Review, 2 (2), Article 5.

Askegaard, Søren and Jeppe T. Linnet (2011) "Towards an epistemology of consumer culture theory: Phenomenology and the context of context," Marketing Theory, 11 (4), 381-404.

Bude, Heinz, and Jörg Dürrschmidt (2010), "What's wrong with globalization?: Contra 'flow speak'-towards an existential turn in the theory of globalization," European Journal of Social Theory, 13 (4), 481-500.

de Koning, Anouk (2009), Global Dreams: Space, Class, and Gender in Middle-Class Cairo. Cairo: American University in Cairo Press.

Figueiredo, Bernardo, Jessica Chelekis, Benet DeBerry-Spence, A. Fuat Firat, Güliz Ger, Delphine Godefroit-Winkel, Olga Kravets, Johanna Moisander, Krittinee Nuttavuthisit, Lisa Peñaloza and Mark Tadajewski (2015), "Developing Markets? Understanding the Role of Markets and Development at the Intersection of Macromarketing and Transformative Consumer Research (TCR)," Journal of Macro Marketing, 35 (2), 257-71.

Ger, Güliz (2017), "Consumption in the web of local and global relations of dominance and belonging," in: Routledge Handbook on Consumption, Margit Keller, Bente Halkier, Terhi-Anna Wilska and Monica Truninger, eds. London: Routledge, 121-34.

Ger, Güliz (1997) "Human Development and Humane Consumption: Well-Being Beyond the Good Life," Journal of Public Policy and Marketing, 16 (1), 110-25.

Ger, Güliz, Eminegül Karababa, Alev Kuruoğlu, Meltem Türe, Tuba Üstüner, and Baskın Yenicioğlu, "Debunking the myths of global consumer culture literature," in The Sage Handbook of Consumer Culture, ed. O. Kravets, P. Maclaran, S. Miles, and A. Venkatesh, eds. forthcoming in 2017 [available at https://www.amazon.co.uk/Sage-Handbook-ConsumerCulture/dp/1473929512]

Gökmen, Özgür (2017), "Jan-Werner Müller, What Is Populism? (2016)," Markets, Globalization \& Development Review, 2 (2), Article 7.

Karanfil, Gökçen and Burcu Eğilmez (2017), "Politics, Culture and Media: Neo-Ottomanism as a Transnational Cultural Policy on TRT El Arabia and TRT Avaz," Markets, Globalization \& Development Review, 2 (2), Article 4. 
Özgün, Aras, Nikhilesh Dholakia, and Deniz Atik (2017), "Marketization and Foucault", Global Business Review, 18 (3) - supplement, S191-S202.

Özgün, Aras, Dicle Yurdakul, and Deniz Atik (2017), "How Do Soap Operas Affect the Poor? Experiences of Turkish Women," Markets, Globalization \& Development Review, 2 (2), Article 2.

Subaşat, Turan (2017), "Turkey at a Crossroads: The Political Economy of Turkey's Transformation," Markets, Globalization \& Development Review, 2 (2), Article 6.

Treske, Andreas (2017), "The Big World - Reha Erdem and the magic of cinema," Markets, Globalization \& Development Review, 2 (2), Article 8.

Watson, Forrest (2017), "Conducting A Communal Questionnaire In Community-Oriented Cultures," Markets, Globalization \& Development Review, 2 (2), Article 3. 